\title{
Parenting Style and Social Skills Developed among the Senior High School Grade 12 Students in Zone IV, Schools Division of Zambales
}

\author{
Patrick Jordan A. Paz ${ }^{1}$, Elizabeth N. Farin ${ }^{2}$, Lilian F. Uy ${ }^{2 *}$ \\ ${ }^{\mathrm{T}}$ Subic District, Department of Education, Division of Zambales, Philippines \\ ${ }^{2}$ President Ramon Magsaysay State University (PRMSU), Iba, Zambales, Philippines \\ Article History \\ Received: 24.02 .2021 \\ Accepted: 07.03.2021 \\ Published: 16.03.2021 \\ Journal homepage: \\ https://www.easpublisher.com

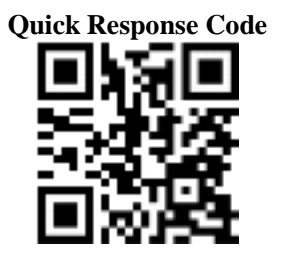 \\ Abstract: This study aimed to determine the relationship between the Parenting Styles and the \\ Social Skills Developed among Senior High School Grade 12 Students in Zone IV, Schools \\ Division of Zambales during S. Y. 2018-2019. The study used the descriptive-survey from \\ Selected Junior High School in Subic District. Authoritative Parenting style was rated by the \\ students as often applied by their parents while Authoritarian, Permissive and Uninvolved \\ Parenting Styles were rated sometimes applied. The senior high school grade 12 students have \\ developed a very satisfactory survival skill, interpersonal skill, problem solving skill and \\ conflict resolution skill. Authoritative Parenting Style has significant relationship to the social \\ skills as to Survival Skill, Interpersonal Skill, Problem Solving Skill and Conflict Resolution \\ Skill. Permissive Parenting Style was also significant correlated to Survival Skill, Interpersonal \\ Skill and Problem Solving Skill; and Neglectful Parenting Style has significant relationship to \\ Survival Skill, Interpersonal Skill and Conflict Resolution Skill. Based on salient findings of \\ the study, and the conclusions arrived at, the researcher recommends the use of authoritative \\ parenting style since students find this as more effective and beneficial to the them. Hence, \\ parents ought to be educated on the importance of adopting the parenting style that would aid \\ in promoting their children's development. \\ Keywords: Parenting styles, Social skills, Grade 12 Students.
}

Copyright (C) 2021 The Author(s): This is an open-access article distributed under the terms of the Creative Commons Attribution 4.0 International License (CC BY-NC 4.0) which permits unrestricted use, distribution, and reproduction in any medium for non-commercial use provided the original author and source are credited.

\section{INTRODUCTION}

Parenting styles were originally conceptualized as transactionally associated with social competence, but studies have mostly focused on parent-to-child effects. Parenting styles create different social environments in the lives of children within the home. Contemporary studies of parenting styles in large part expand on several concepts put forward in Baumrind's [1] formative research in the 1960s, which outlined a three- group classification system. Since the advent of this type of research, generally conducted through direct observation and by questionnaires and interviews with parents and children, classification has been based on evaluations along two broad dimensions of parenting styles: control/demandingness (claims parents make on a child relating to maturity, supervision and discipline) and responsiveness (actions that foster individuality, self-regulation and self-assertion by being attuned and supportive). Contemporary researchers typically classify parenting styles in four groups: authoritarian parenting, characterized by high levels of control and low levels of responsiveness; indulgent permissive parenting, characterized by low levels of control and high levels of responsiveness; authoritative parenting, characterized by high levels of both control and responsiveness; and neglectful parenting, characterized by lack of both control and responsiveness.
Developing an appropriate parenting style at the modern society where learners are born into a world of information technology and think and behave differently than those from previous generations is very important, especially when not all sources agree. Research on effective parenting styles can help guide parents to a proper balance of sensitivity and control.

\section{ObJectives of The Study}

This study will focus on the relationship of Parenting styles and the Social Skills Developed among grade 12 students in Zone IV of the Schools Division of Zambales. Specifically, the researcher aimed to answer the following questions:

1. How are the parenting styles of parents towards their children described?

2. How are the social skills developed among the grade 12 senior high school students in terms of the following:
a. Survival Skill
b. Interpersonal Skill
c. Problem Solving Skill
d. Conflict Resolution Skill?

3. Is there significant relationship between parenting styles and social skills developed? 


\section{FRAMEWORK OF THE STUDY}

While various typologies of parenting styles have been developed and utilized in literature, typology (authoritative, authoritarian and permissive styles) has largely been accepted as very comprehensive. Consequently, the current study utilized this typology to assess the relationship between parenting styles and children's social development. The concept parenting style is viewed as a characteristic of a parent that changes the effectiveness of family socialization practices and children's receptiveness to such practices [2]. Parenting styles are broad patterns of childrearing practices, values, and behaviors. It is the way parents take care of their children which can have impact on the children's personality development and the ways of interacting with social and close relations [3]. While various typologies of parenting styles have been developed and utilized in literature, Baumrind [1] typology (authoritative, authoritarian and permissive styles) has largely been accepted as very comprehensive. Consequently, the current study utilized this typology to assess the relationship between parenting styles and children's social development.

Research findings demonstrate that an authoritative parenting style produces a number of positive developmental outcomes in adolescents. An authoritative parenting style that includes parental monitoring and supervision promotes teen's exposure to positive activities and reduces teen's opportunities for engaging in delinquent, risky behaviors [4]. A warm but firm approach to parenting allows teens to be independent within developmentally appropriate parental limits and boundaries.

Research suggests that in order to be a growthfacilitating parent who uses an authoritative parenting style, one would have to be a mature, psychologically healthy adult [5]. Age and intelligence is often used as a determinant when discussing maturity and research shows that the older the mother is, the more she interacts with her children in a positive stimulating and sensitive manner $[5,6]$. To further support this claim, research shows that younger mothers express a negative attitude toward parenting, exercise a punitive authority, have unrealistic expectations of development, are less responsive to their newborns, and engage infants in less verbal interactions [5, 7]. Mature parenting, involving warmth, acceptance, and helpfulness toward the child, can also be identified by an internal locus of control, high levels of interpersonal trust, and the ability to cope with distress [5].
When parents are struggling with diagnosed or undiagnosed psychological distress, they are not able to parent as effectively [5, 6]. Mothers who are suffering from depression are more likely to create disruptive, hostile, and rejecting home environments for their children [5]. Parents' thoughts and feelings in regard to parenting will impact their parenting style, in addition to the thoughts and feelings that are aroused when they think about their own upbringing [6, 8]. Hence, developmental history is also included into parents' psychological well-being. Parents who experienced mistreatment in their childhood are more likely to mistreat their own children [5]. In addition, parents who have experienced separation from their caregivers during their childhood are often found to have difficulties building relationships caring for their own children $[5,9]$.

Socially competent behavior reflects effective social interactions such as getting along well with others, initiating play, entering play, and resolving conflict with peers. Pro-social behavior which is one of the behavioral dimensions of social competence, is defined as voluntary action intended to benefit the others [10]. Parental influence on a child's social competence within peer groups has been investigated for a long time. Many previous studies have focused on authoritative, authoritarian, and permissive parenting styles and their associations with several measures of child competence $[11,2]$.

Several researchers have found that preschool children who witnessed authoritative parenting style had higher social competence [12-14].

On the other hand, the parents who show authoritarian parenting style make their children have hostile behaviors [15-17]. Social competence's and prosocial behaviors' relationship with the parenting style change according to the parents' or the child's sex [13, $18,19]$. In these studies, it was found that fathers' authoritarian style is a better predictor of the children's hostile behaviors; the girls' social competence scores are higher than the boys, and the girls tend to show less aggressive behavior than the boys $[13,20]$.

In our country there are only a few researches investigating the relationship between the parenting styles and social competence and the parenting styles and pro-social behaviors. The results of these studies are not in agreement with each other. Some researchers indicated that the social competence and pro-social behaviors are not related with the parenting style. On the other hand, others showed that the mothers' 
authoritative parenting style was positively correlated with pro-social. In the related literature, quality of care was also found to be an important predictor of child outcomes. Although there isn't any research examining the effects of type of day care centers (state or private) on child outcomes, a research investigated the influence of specific quality indicators of day care centers (teacher-child ratio, group size, square footage per child, characteristics of the activities which were picture book reading, educational activities) on the social competence of day care children [21].

\section{Materials AND Methods Research Design}

It made use of the descriptive-survey, checklist method and rubrics. The methods involved range from the survey which describes the status quo, the correlation study which investigates the relationship between variables, to development studies which seek to determine changes overtime [22].

\section{Respondents and Location of the Study}

The respondents of the study were the random three hundred (300) Grade 12 senior high schools students who are enrolled in public secondary schools in Zone 4, Division of Zambales, Philippines. The Zone IV is a group of three municipalities from the Province of Zambales namely Subic, Castillejos and San Marcelino. Table-1 shows the distribution of the respondents.

Table-1: Distribution of the Respondents

\begin{tabular}{|l|l|l|}
\hline District & Frequency & Percent \\
\hline Castillejos & 119 & $39.7 \%$ \\
\hline San Guillermo & 65 & $21.7 \%$ \\
\hline Subic & 116 & $38.7 \%$ \\
\hline Total & $\mathbf{3 0 0}$ & $\mathbf{1 0 0 . 0 \%}$ \\
\hline
\end{tabular}

\section{Instrument Tool}

The main tool that the researcher used in the data gathering process was a researcher-made questionnaire. The questionnaire consists of two parts: Part I contains parameters to determine social skills that include Survival Skill, Interpersonal Skill, Problem Solving Skill and Conflict Resolution Skill).; Part III (a checklist of guide questions and observation sheet designed to acquire the parenting styles adapted from Shyny [23] of Bharathiar University-Coimbatore).

\section{RESULTS AND DISCUSSION Parent's Parenting Styles}

Table-2 shows the parenting styles of parents whether authoritarian, authoritative, permissive and neglectful.

\section{Table-2: Parenting Styles of Parents towards the} Senior High School Grade 12 Students

\begin{tabular}{|l|l|l|}
\hline Parenting Styles & Mean & Description \\
\hline Authoritarian & 3.00 & Sometimes \\
\hline Authoritative & 3.53 & Often \\
\hline Permissive & 3.11 & Sometimes \\
\hline Neglectful & 2.87 & Sometimes \\
\hline Mean & $\mathbf{3 . 1 3}$ & Sometimes \\
\hline
\end{tabular}

Most parents were found authoritative towards their children with the highest mean of 3.53 which is described as often. This indicates that parents want to be friends and guide to their children but because of busy schedules, they can only occasionally visit them in school to know their children's progress. They understand their children's feelings in any situation and try to get their opinion whenever they will buy something for them, give their children full freedom to share everything with them, often set some appropriate rules and give friendly corrections whenever necessary as they understand their children's strengths and weakness; and help their children to set a realistic goal without any force for their future career.

Some parents were also authoritarian who want their children to follow their instructions because they are the authority to decide what to do or what not to do yet seldom give physical punishment than giving advice because they think that their children will not listen to it. They have sometimes little patience to tolerate any of their children's misbehavior, give a strict time table for their children to follow, have clear expectations regarding their children's behavior, scold and criticize them for showing disobedience and sometimes believe that only through punishment that their children can be corrected and sometimes do not also like to give them any financial freedom. Parents were also permissive to their children. They do not often give any punishments rather they make the respondents feel that they will become better next time whenever the children have come with low marks. This indicates that the parents sometimes very soft with me that they would not correct me at proper time by punishment; have a definite goal and planning about their future but sometimes cannot follow it strictly because of their leniency. Also, they sometimes give valuable reward for obeying them or behaving well; 
Patrick Jordan A. Paz et al; EAS J Humanit Cult Stud; Vol-3: Iss-2 (Mar-Apr, 2021): 79-85

sometimes liberal with them and sometimes threaten them but do not actually do it.

Some students also rated their parents to exhibit neglectful parenting style with a rating of 2.87 and described as sometimes used. Parents are sometimes busy and get little time to care for their children, it leads the respondents become sometimes quite free to move on way to take their own decisions. Nevertheless, an indicator with lowest mean rating means that parents sometimes ignore their children's misbehavior and sometimes have no idea about their children's lives.

Table-3 reveals that the social skills which were described in terms of survival, interpersonal, problem solving and conflict were rated very satisfactory by the Grade 12 students. The highest rating was obtained from problem solving skills with a rating of 4.13 .

Table-3: Social Skills of Senior High School Grade 12 Students

\begin{tabular}{|l|l|l|}
\hline Skills & Mean & Description \\
\hline Survival Skills & 3.69 & Very Satisfactory \\
\hline Interpersonal Skills & 3.92 & Very Satisfactory \\
\hline Problem Solving Skills & 4.13 & Very Satisfactory \\
\hline Conflict Resolution Skills & 3.74 & Very Satisfactory \\
\hline Mean & $\mathbf{3 . 8 7}$ & Very Satisfactory \\
\hline
\end{tabular}

Results indicate that the Grade 12 students were able to apologize when done something wrong and to ask help when having difficulty doing something. The rating of problem solving skills is followed by interpersonal skills with a rating of 3.92. The students' high rating was due to their ability to show respect for someone's ideas, feelings and interests when talking to them. They were also helpful to those who need their help. The conflict resolution skills of the students was also very satisfactory with a rating of 3.74 . The students can deal positively when left out of some school activities and are able to control their temper when they are upset and can stay in control when being bullied. The students listen to someone who is taking to them and pay full attention to whatever they are doing.

\section{Relationship between Parenting Styles and the Grade 12 Student's Social Skills}

Table-4 shows the Spearman Rank Correlation Coefficients of the Social Skills of the Senior High School Grade 12 Students and their Parent's Parenting Styles. The data being an ordinal type, Spearman's Rho Correlation was run using the SPSS between the two variables and was tested at a significance level of .05.

Table-4: Relationship between Parenting Styles and the Social Skills

\begin{tabular}{|l|l|l|l|l|l|}
\hline \multicolumn{2}{|c|}{} & Authoritarian & Authoritative & Permissive & Neglectful \\
\hline \multirow{3}{*}{$\begin{array}{l}\text { Survival } \\
\text { Skill }\end{array}$} & Correlation Coefficient & .105 & $.156^{* * *}$ & $.210^{* *}$ & $.148^{*}$ \\
\cline { 2 - 6 } & Sig. (2-tailed) & .068 & .007 & .000 & .010 \\
\cline { 2 - 6 } & $\mathrm{N}$ & 300 & 300 & 300 & 300 \\
\hline \multirow{3}{*}{$\begin{array}{l}\text { Inter- } \begin{array}{l}\text { pesonal } \\
\text { Skill }\end{array} \\
\text { Problem Solving Skill }\end{array}$} & Correlation Coefficient & .093 & $.264^{* *}$ & $.217^{* *}$ & $.129^{*}$ \\
\cline { 2 - 6 } & Sig. (2-tailed) & .110 & .000 & .000 & .025 \\
\cline { 2 - 6 } & $\mathrm{N}$ & 300 & 300 & 300 & 300 \\
\cline { 2 - 6 } & Correlation Coefficient & .025 & $.179^{* *}$ & $.188^{* *}$ & .110 \\
\cline { 2 - 6 } & Sig. (2-tailed) & .663 & .002 & .001 & .056 \\
\hline \multirow{3}{*}{$\begin{array}{l}\text { Conflict Resolution } \\
\text { Skill }\end{array}$} & $\mathrm{N}$ & 300 & 300 & 300 & 300 \\
\cline { 2 - 6 } & Correlation Coefficient & .045 & $.192^{* *}$ & .102 & $.138^{*}$ \\
\cline { 2 - 6 } & $\mathrm{N}$ & .441 & .001 & .079 & .017 \\
\hline
\end{tabular}

$*$ Significant at $5 \%$ alpha $* *$ Significant at $1 \%$ alpha

Results of the test revealed that there is no significant relationship between the Authoritarian Parenting Style and the Social Skills as to Survival Skill $(\mathrm{r}=0.105)$, Interpersonal Skill $(\mathrm{r}=0.093)$, Problem
Solving Skill $(\mathrm{r}=0.025)$, and Conflict Resolution Skill $(\mathrm{r}=0.045)$. This shows that at 0.05 alpha level, social skills of the respondents are not significantly associated on the parent's authoritarian parenting style. 
Authoritarian parenting includes strict parental demand, with very minimal to no parental support, or warmth [1]. These parents often use coercion or force, in order to create submissive children, as the parent's goal is to create prompt obedience from their children. The directives in this family environment are not to be questioned or challenged, even though parents do not always supply explanations or reasoning for their decisions [24]. This may hinder children's problem solving skills, as they are taught to immediately accept a directive rather than to think for themselves. It is rarely accepted for children to gain individuality and autonomy; instead parents strive to create conformity [1].

The results also show that there is no significant relationship between the Permissive Parenting Style and the Conflict Resolution Skill ( $\mathrm{r}=$ 0.102); and between the Neglectful Parenting Style and the Problem Solving Skill $(\mathrm{r}=.110)$.

The permissive type on the other hand included children raised in families with low levels of demand and control, but high levels of warmth and responsiveness. These children were immature in their behavior with peers, were aggressive and were not likely to be independent or take on responsibility. The neglecting type was associated with the most consistent negative outcomes. These children demonstrated disturbances in relationships with peers and adults. By adolescence they were impulsive, antisocial and demonstrate low levels of achievement [25].

On the other hand, the computed correlation coefficients as shown in the table 16 reveal that Authoritative Parenting Style has significant correlation to the social skills. Permissive Parenting Style also shows significant relationship to Survival Skill, Interpersonal Skill and Problem Solving Skill while Neglectful Parenting Style has a significant correlation to Survival Skill, Interpersonal Skill and Conflict Resolution skill.

Authoritative Parenting Style. The computed correlation coefficients reveal significant relationship between the variables as follows: (a) $r=0.156$ reveals a very weak positive correlation between Authoritative Parenting Style and Survival Skill; (b) $r=0.264$ reveals a weak positive correlation between Authoritative Parenting Style and Interpersonal Skill; (c) $r=0.179$ reveals a very weak positive correlation between Authoritative Parenting Style and Problem Solving Skill and (d) $\mathrm{r}=0.190$ reveals a very weak positive correlation between the Authoritative Parenting Style and the Conflict Resolution Skill. This implies that at .01 alpha level, Authoritative Parenting Style is significantly associated with the four Social Skills.

The authoritative style balances clear, high expectations with emotional support and recognition of children's autonomy. The authoritative parent tries to direct the child, but in a rational manner [1]. Such a parent encourages give and take but shares the reasoning behind his or her rules. These parents value both autonomous self-will and disciplined conformity. They exercise firm control with certain points but the child is not tied up with restrictions [1]. According to Miller [26], an authoritative parent's goal is to prepare children to live fully autonomous lives upon adulthood. As a result, when compared with the three other parenting styles, children who have been raised in authoritative homes score higher on a many measures including: competence, social development, selfperceptions, and mental health.

There is a significant relationship between the Permissive Parenting Style and the students' Survival Skill $(\mathrm{r}=0.210)$ which implies weak positive correlation and significant at 0.01 alpha level. Significant correlation is also present between the Permissive Parenting Style and Interpersonal Skill ( $\mathrm{r}=$ 0.217 ) which indicates weak positive correlation and significant at 0.01 alpha level. Lastly, the result revealed significant relationship between Permissive Parenting Style and the Problem Solving Skill with computed correlation coefficient of $r=0.188$ which means very weak correlation and significant at 0.01 alpha level.

The permissive parent attempts to behave in a non-punitive, accepting, and affirmative manner towards the child's impulses, desires, and actions Baumrind, 1991 [1]. Parents who adopt this type of parenting consider self-regulation to be the right of a child to live freely without outside authority. With this type of parenting, few demands are made of the child regarding such things as chores. This type of parenting does not require the parent to act as an active agent responsible for shaping or altering the child's behavior Baumrind, 1991 [1]. The child is allowed to regulate his or her own activities. The parent does not control the child nor encourages the child to obey external standards.

Neglectful Parenting Style has significant relationship to Survival Skill $(r=0.148)$, Interpersonal Skill $(r=0.129)$ and Conflict Resolution Skill $(r=$ 
0.138) which implies very weak correlation and significant at 0.05 alpha level.

Research supports that adolescents of uninvolved parents learn that parents tend to be interested in their own lives and less likely to invest much time in parenting. As a result, teens generally show similar patterns of behavior as adolescents raised in permissive homes and they may also demonstrate impulsive behaviors due to issues with self-regulation. But not all children of neglectful parents end up this way. According to Miller [26] there are some intervening factors that can prove helpful. One factor is if the child encounters health adults who are genuinely interested in their growth. The second factor is a child who is more "resilient". Psychological resilience is the ability to cope with extremes of stress. Those who are psychologically resilient have the capacity to make something of their lives even in the face of childhood neglect. It is in large part for this reason that some children of neglectful parents go on to have successful lives while others, sometimes living in the same childhood home, remain stuck throughout their lives. It must be understood that the children who were left "alone" at an early age were forced to learn and provide for themselves to a certain degree. Parents who have little time to spare practice this method to allow their kids to grow on their own. This could also lessen the probability of developing post-traumatic stress disorder children may experience in the hands of authoritarian parents.

\section{Conclusions}

The study drew the following conclusions: Most parents are showing authoritative parenting style to their children. Parents are sometimes authoritarian, permissive and uninvolved in handling their children. In terms of social skills, Grade 12 students are very satisfactory in terms of survival, interpersonal, problem solving and conflict resolution.

Authoritative Parenting Style is significantly related to the social skills as to Survival Skill, Interpersonal Skill, Problem Solving Skill and Conflict Resolution Skill and significant at .01 alpha level. Permissive Parenting Style was also significant correlated to Survival Skill, Interpersonal Skill and Problem Solving Skill; and significant at 0.01 alpha level; and Neglectful Parenting Style has significant relationship to Survival Skill, Interpersonal Skill and Conflict Resolution Skill, significant at 0.05 alpha level.
On the other hand, there is no significant correlation between authoritarian parenting Style and the Social Skills developed among Senior High School Grade 12 Students.

\section{RECOMMENDATIONS}

Based on salient findings obtained in the study, and the conclusions arrived at, the researcher offer the following recommendations:

1. The finding of this study recommends the adoption of authoritative parenting style since is associated with healthy adolescent development and provides a balance between affection and support and an appropriate degree of parental control in managing adolescent behavior. This atmosphere provides opportunities for the adolescent to become self-reliant and to develop a healthy sense of autonomy within a set of parental limits, guidelines and rules.

2. Parent must be well aware of the negative and positive impacts of the various parenting styles on students' academic and non-academic gains especially to social skills of their children. Hence, parents ought to be educated on the importance of adopting the parenting style that would aid in promoting their children's development.

3. Future researchers should conduct, support research and development that identifies best ways of parenting the children.

\section{REFERENCES}

1. Baumrind, D. (1991). The Influence of Parenting Style on Adolescent Competence and Substance Use. Journal of Early Adolescence, 11(1), 56-95.

2. Darling, N., \& Steinberg, L. (1993). Parenting style as context: An integrative model. Psychological bulletin, 113(3), 487-496.

3. Akhtar, Z. (2012). The effect of parenting style of parents on the attachment styles of undergraduate students. Language in India, 12(1), 555-566.

4. Wargo, E. (2007). Adolescents and risk: Helping young people make better choices, ACT for Youth Center of Excellence: Research Facts and Findings.

5. Belsky, J. (1984). The determinants of parenting: A process model. Child development, 83-96.

6. Chase-Lansdale, P. L., \& Pittman, L. D. (2002). Welfare Reform and Parenting: Reasonable Expectations. Children and Welfare Reform, 12(1). 
7. Field, T. M., Widmayer, S. M., Stringer, S., \& Ignatoff, E. (1980). Teenage, lower-class, black mothers and their preterm infants: An intervention and developmental follow-up. Child development, 426-436.

8. Rowinski, K. S., \& Wahler, R. G. (2010). Clinicreferred mothers' autobiographical narratives as markers of their parenting styles. Journal of Child and Family Studies, 19(6), 714-719.

9. Frommer, E. A., \& O'Shea, G. (1973). The importance of childhood experience in relation to problems of marriage and family-building. The British Journal of Psychiatry, 123(573), 157-160.

10. Schneider, B. H. (1993). Children's social competence in context: The contributions of family, school and culture (Vol. 10). Psychology Press.

11. Baumrind, D. (1971). Harmonious parents and their preschool children. Developmental psychology, 4(1), 99-102.

12. Dornbusch, S. M., Ritter, P. L., Leiderman, P. H., Roberts, D. F., \& Fraleigh, M. J. (1987). The relation of parenting style to adolescent school performance. Child development, 1244-1257.

13. Hart, C. H., Nelson, D. A., Robinson, C. C., Olsen, S. F., \& McNeilly-Choque, M. K. (1998). Overt and relational aggression in Russian nurseryschool-age children: Parenting style and marital linkages. Developmental psychology,34(4), 687697.

14. Hoeve, M., Dubas, J. S., Eichelsheim, V. I., Van der Laan, P. H., Smeenk, W., \& Gerris, J. R. (2009). The relationship between parenting and delinquency: A meta-analysis. Journal of abnormal child psychology, 37(6), 749-775.

15. Aunola, K., \& Nurmi, J. E. (2005). The Role of Parenting Styles in Children's Problem Behavior. Child Development, 76(6), 1144-1159.

16. Benzies, K., Keown, L. A., \& Magill-Evans, J. (2009). Immediate and Sustained Effects of Parenting on Physical Aggression in Canadian Children Aged 6 Years and younger. The Canadian Journal of Psychiatry, 54, 55-64.
17. Chen, G., Chen, X., \& Yue, P. L. (2000). Electrocoagulation and electroflotation of restaurant wastewater. Journal of environmental engineering, 126(9), 858-863.

18. Ladd, G. W., \& Ladd, B. K. (1998). Parenting behaviors and parent-child relationships: Correlates of peer victimization in kindergarten?. Developmental psychology, 34(6), 1450 .

19. DeWolf, M. I. C. H. E. L. E., \& Benedict, J. O. A. N. (1997). Social development and behavior in the integrated curriculum. Integrated curriculum and developmentally appropriate practice, 257-284.

20. Russel, M. G., Volovics, A., Schoon, E. J., van Wijlick, E. H., Logan, R. F., Shivananda, S., \& Stockbrügger, R. W. (1998). Inflammatory bowel disease: is there any relation between smoking status and disease presentation?. Inflammatory bowel diseases, 4(3), 182-186.

21. Micozkadığlu, İ. İ., \& Berument, K. S. (2003). Okulöncesi Kurumların Kalitesi Ve Cocukların Sosyal Yeterliği. Türk Psikoloji Dergisi, 18(51), 79-93.

22. Key, T. J., Verkasalo, P. K., \& Banks, E. (2001). Epidemiology of breast cancer. The lancet oncology, 2(3), 133-140.

23. Shyny, T. Y. (2017). Construction and Validation of PS-FFQ (Parenting Style Four Factor Questionnaire, Bharathiar University Coimbatore. IJEDR. 5(3), 2321-9939.

24. Moore, F. A., Feliciano, D. V., Andrassy, R. J., McArdle, A. H., Booth, F. V., MorgensteinWagner, T. B., ... \& Moore, E. E. (1992). Early enteral feeding, compared with parenteral, reduces postoperative septic complications. The results of a meta-analysis. Annals of surgery, 216(2), 172.

25. Maccoby, E. E. (1992). The Role of Parents in the Socialization of Their Children: A Historical Overview, Developmental Psychology, 28, 10061017.

26. Miller, M. J. (2010). Social Learning and Imitation. New Haven, CT: Yale University Press.

Cite This Article: Patrick Jordan A. Paz et al (2021). Parenting Style and Social Skills Developed among the Senior High School Grade 12 Students in Zone IV, Schools Division of Zambales. EAS J Humanit Cult Stud, 3(2), 79-85. 